\title{
Galileo, Poetry, and Patronage: Giulio Strozzi's Venetia edificata and the Place of Galileo in Seventeenth-Century Italian Poetry*
}

\author{
by CRYSTAL HALL
}

\begin{abstract}
The Venetian poet and librettist Giulio Strozzi (1583-1652) spent much of his career glorifying the Serenissima through a series of theatrical pieces. His only epic poem, the Venetia edificata (1621, 1624), while ostensibly a celebration of the republic, shows a level of commitment to Galileo Galilei (1564-1643) and to Galileo's science that is unique among poets of the time, Venetian or otherwise. It is the apex of Strozzi's artistic project to incorporate Galileo's discoveries and texts into poetic works. The Venetia edificata also represents the culmination of a fifteen-year effort to gain patronage from the Medici Grand Dukes in Florence. While the first, incomplete version is dedicated to the Venetian Doge, the second, finished version is dedicated to Grand Duke Ferdinando II de' Medici of Florence. More than a decade after Galileo's departure from the Veneto to Florence, Strozzi cites from Galileo's early works, creates a character inspired by Galileo, incorporates the principles of Galileo's science into the organizing structure of the poem, and answers one of Galileo's loudest complaints about Torquato Tasso's Jerusalem Delivered (1581). Strozzi's strategies both in writing the Venetia edificata and in seeking patronage for it underscore the ambivalent response to Galileo in contemporary poetry.
\end{abstract}

\section{INTRODUCTION}

I n canto 7 of Giulio Strozzi's epic poem Venetia edificata (Venice Edified, $1621,1624)$, the wise magician Merlin presents to the Frankish warrior Oddo an instrument that will help to free the citizens of Aquileia from the siege of the Huns: a long tube fitted with a concave lens at one end and a convex lens at the other (fig. 1). In the context of the poem, the occhiale, or telescope, is slightly more than 1,200 years early for its debut into the Venetian military scene. For the moment this neglect of history can be permitted: after all, the author's poetic model, Ludovico Ariosto's (1474-1533) Orlando furioso $(1516,1532)$, includes the famous scene of Orlando tossing Cimosco's anachronistic firearm into the ocean. This is also not the first

*I sincerely thank the anonymous readers for Renaissance Quarterly for their helpful and insightful recommendations that strengthened this project. Portions of this research were funded by a Newberry Consortium Grant through the University of Kansas, for which I am also grateful. All translations are the author's, except where otherwise noted. 


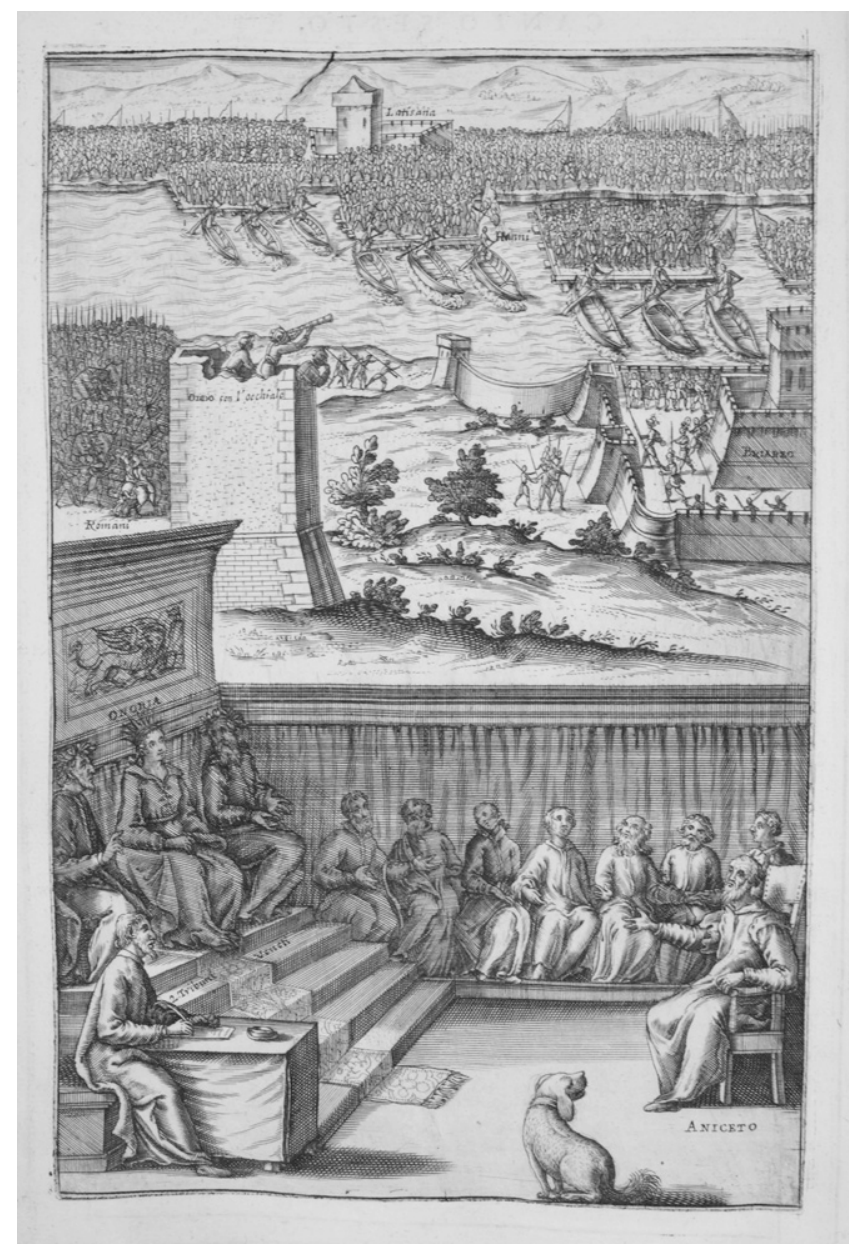

FIGURE 1. Opening image of canto 7 of the Venetia edificata. Venice, 1624, 60. Photo courtesy of the Newberry Library, Chicago. Wing folio ZP.635.P65.

time that Galileo Galilei (1564-1642) or his telescope make an appearance in popular literature of the seventeenth century. ${ }^{1}$ Rather, it is the descriptive language that accompanies the illustration that makes Strozzi's work unique. Given recent critical engagements with questions of the relationship between the sciences and literature, Strozzi's case offers the opportunity to examine the ways in which a literary author sought to capitalize on the courtly and thematic value of Galileo's new science in a variety of settings.

${ }^{1}$ Steiner, 1-10; Aït-Touati, 45-75. 
The poem at the center of this study is a text heavy with references to Galileo's scientific ideas and innovations, written by a Venetian, but published over a decade after Galileo had transferred from the Veneto to Florence. Strozzi writes extensively about the foundation of Venice, and dedicates the poem entirely to the doge in its incomplete 1621 edition, but in the final, complete edition and its subsequent reprints adds only Tuscan, rather than Venetian, allusions. In that later edition, Strozzi notably includes a second dedication to Ferdinando II de' Medici, Grand Duke of Tuscany, that shows his willingness to use a vehicle of Venetian patriotism to advance his Florentine ambitions. In so doing, Strozzi's fictional account of the telescope becomes more than an anachronistic nod to a popular image of his own time, and instead demonstrates the value of a poetic occhiale as a courtly, philosophical, and literary device.

Giulio Strozzi (1583-1652), also known as Luigi Zorzisto, was a Venetian playwright and poet who earned his reputation through the publication of orations, plays, poetry, and ceremony descriptions before his career as a librettist gained momentum in the late $1620 \mathrm{~s}^{2}$. Although he worked with Claudio Monteverdi (1567-1643), Strozzi might be best known in modern operatic studies as the adoptive father of his likely illegitimate daughter Barbara (1619-77), a Venetian composer. ${ }^{3}$ Strozzi's early studies took him to Pisa, where he studied law, and then to Rome, where he wrote a funerary oration for Ferdinando I de' Medici in 1609. He attended Galileo's demonstrations on sunspots in 1612, and then wrote the Erotilla (1615) for the marriage of Roman Marcantonio Borghese (1598-1658) and Camilla Orsini (1603-85). After living in Padua and Urbino, he returned to settle in Venice in 1620, publishing the first twelve cantos of the Venetia edificata in 1621, the final twenty-four-canto edition in 1624, and his play Barbarigo in 1625 . He then turned primarily to musical productions.

A member of the religiously skeptical and libertine Accademia degli Incogniti, and a founding member of the Venetian Accademia degli Unisoni, his other work includes primarily libretti, such as Il Natal di Amore: anacronismo (The Birth of Love: Anachronism, 1621) that became the Gelosia placata (Jealousy Placated, 1629) by Giovanni Rovetta (1596-1668), and three collaborations with Monteverdi: La Finta pazza Licori (The Feigned Madwoman Licori, 1627), Proserpina rapita (Persephone Abducted, 1630), and the collection of sonnets I Cinque fratelli (The Five Brothers, 1628). The Finta pazza had a long life, starting as a play, then a projected opera with Monteverdi, and finally as the Feste theatrali per la Finta pazza

${ }^{2}$ Ferrari, 645; Soranzo, 214; Michaud and Gabriel, 55:240-41; Pirrotta, 9:515.

${ }^{3}$ E. Rosand, 1990, 110-53. 
(Theatrical Festivals for the Feigned Madwoman), performed in Venice in 1641, later in Paris at the court of Louis XIV in 1645, and in Florence that same year. ${ }^{4}$ The popularity of the piece even prompted a booklet of theatrical propaganda that incorporates Galileo's instrument, Il Cannocchiale per la Finta pazza (The Telescope for the Feigned Madwoman, 1643). Strozzi's La Delia o sia la Sera sposa del Sole (Delia, or the Night, Wife of the Sun, 1639) has been called the "prototype of Venetian opera." This was followed by an ode to a soprano who frequently appeared in his productions, and Il Romolo, e Remo (Romulus and Remus, 1645). The Finta pazza, Finta savia and Romolo, e Remo are connected to the Venetia edificata through their common underlying propagandistic efforts that contributed to establishing the social, economic, and political qualities that historians now refer to as the myth of Venice. ${ }^{6}$ Strozzi also left behind several unpublished works, including a translation of the Spanish picaresque tale Lazarillo de Tormes. ${ }^{7}$ His portrait now hangs in the Uffizi Gallery in Florence.

Strozzi was clearly committed to the glorification of Venice and the Veneto through poetic and theatrical pieces. Yet the most obvious example of this patriotic project, Venetia edificata, represents the pinnacle of a parallel program of incorporating the philosophy of the Tuscan scientist Galileo into his work. Strozzi had a long association with Tuscan culture and patronage. He had already approached the Medici for patronage before Galileo's published volumes achieved their widest circulation, starting in 1623 with the Assayer. He wrote and organized the funeral rites for Ferdinando I de' Medici in Rome (1609) and for his successor Cosimo II in Venice (1621), and wrote sonnets for Ferdinando II's visit to Venice in 1628. 'The Venetia edificata represents a merging of interests and, title notwithstanding, is as much a Tuscan as a Venetian work. Strozzi cites Galileo's chief works published prior to 1621, the year of publication of the twelve-canto edition. Furthermore, Strozzi ventriloquizes Galileo himself, imitates Galileo’s favorite

${ }^{4}$ Michelassi, 314

${ }^{5}$ Osthoff, 20.

${ }^{6} \mathrm{E}$. Rosand, 2007, 12-14.

${ }^{7}$ Negri, 312-13. Strozzi's translation has recently appeared in a critical edition: see Strozzi, 1990.

${ }^{8}$ Macandrew, 266.

${ }^{9}$ The full titles are Orazione funebre recitata nell'Esequie fatte in Roma dalla Nazione Fiorentina al Ser. Ferdinando I Il Gran Duca di Toscana (Venice, 1609), Esequie fatte in Venetia dalla natione Fiorentina al Serenissimo D. Cosimo II Quarto Gran Duca di Toscana. Il di 25 di Maggio, 1621 (Venice, 1621), and Le sette giornate nelle quali hebbe Venetia $i$ serenissimi principi d. Ferdinando II Gran Duca di Toscana e d. Gio. Carlo de' Medici suo fratello sonetti (Venice, 1628). 
poet Ariosto, and corrects one of what Galileo considered to be Torquato Tasso's (1544-95) greatest mistakes in the Gerusalemme liberata (Jerusalem Delivered, 1581). He distinguishes the Edificata from other epic poems and histories written for the glory of the Venetian republic in this period with these distinctly Tuscan touches.

\section{Galileo And the Glories of Venice}

By the time Strozzi published the unfinished, 1621 edition of the Edificata, the Medici family had already been Galileo's patron for eleven years. It was a lucrative, but precarious, intellectual situation for Galileo. He had perfected his first telescope while he was a professor of mathematics at the University of Padua and while also juggling side jobs as a multidisciplinary tutor and an artisan of mechanical instruments. The environment in the Veneto was conducive to experimentation: the deteriorating relationship between Venice and Rome allowed presses and authors more access to prohibited books and less pressure from ecclesiastical censors than their counterparts in Rome or Florence. ${ }^{10}$ After presenting the telescope to the doge in 1609, Galileo lobbied for a better position at the university, with a significant raise and a lifetime contract at Padua. The contract meant Galileo would still need to teach and that he could no longer negotiate salary increases, freezing him at a lower income than his friendly rival in philosophy, and another author on Venice, Cesare Cremonini (1550-1631). In spring of 1610, Galileo published the Sidereus nuncius (Starry Messenger), his journal of observations of mountains on the moon and on the satellites around Jupiter that he subsequently named the Medicean stars. Strozzi would draw heavily on the text when composing the funerary memorials for Cosimo II in 1621 and the later Venetia edificata. Galileo conducted his first observations of the rings of Saturn at the same time as he studied the moon and the Medicean stars, but only published the results two years later in works that would also become sources for Strozzi's poetic repertoire.

After spending what he called the happiest years of his life in the Veneto, Galileo was able to negotiate even higher pay and fewer responsibilities in the Medici court through a series of gifts, letters, and honors. ${ }^{11}$ In both the funerary memorial for Cosimo II in 1621 and the Edificata in 1624, Strozzi noted that Galileo had sent telescopes to Ferdinando I de' Medici (1549-1609) while negotiating a position as court mathematician and philosopher, and then continued in the role of tutor to Cosimo II (1590-1621). Galileo left the Veneto before receiving any of the higher salary that he had

\footnotetext{
${ }^{10}$ Grendler, 280.

${ }^{11}$ Heilbron, 147-60; Westfall; and see more generally Biagioli, 1993, 103-58.
} 
negotiated there, and his hasty departure was not well received. This may in part explain why there are so few references to him in Venetian literature of the early seventeenth century.

This was a time when Venice was the subject of numerous laudatory works and updated historical chronicles that expanded on what would later be known as the myth of Venice. These include not just epic poetry like Strozzi's, but collections of poems and theological discussions of the city's glory and destiny. The frequently reprinted chronicles of Venetian history presented foundational myths for the city and selectively reported the most important events of recent decades. For example, Fedele Onofri (fl. 1640), wrote a popular chronicle extending from the foundation of Venice in the time of the Roman Empire to $1663 .^{12}$ Onofri presented a detailed geography of the city that noted the characteristics and famous buildings of each district of the city, and included exhaustive lists of ecclesiastical dignitaries, princes, and other notable citizens; yet Onofri makes no mention of Galileo. Giovanni Nicolò Doglioni (ca. 1548-1629) also ignored Galileo in the second edition of his Compendio storico (Historical Compendium, 1618). ${ }^{13}$ None of the histories written at the time mention Galileo's presentation of the telescope to the doge in 1609, even though they do frequently report on other matters of contemporary literary and political interest and discuss several of the people with whom Galileo corresponded, including Francesco Contarini and Cardinal Bellarmine. ${ }^{14}$

Many of these chronicles devoted great attention to determining the details of when and how Venice was built. There was some consensus on the general outlines, and significant difference when it came to particular details. Francesco Sansovino (d. 1586) described three foundations of Venice in his work Venetia città nobilissima, et singolare (Venice, Most Noble and Singular City, 1581) and Strozzi followed this model in the Edificata. Sansovino documented at length various wars and conflicts, the lives of princes and writers, and accounts of buildings, laws, orders, and customs. ${ }^{15}$ In a 1663

${ }^{12}$ Onofri, A5.

${ }^{13}$ For the complete title, see Doglioni.

${ }^{14}$ A. Morosini, 690-92.

${ }^{15}$ Sansovino began his history with the traditional narrative that Antenor led the first inhabitants to the region. After the descent of the Huns south of the Alps, they fled to the lagoon to establish what he describes as a culturally independent entity. The summary "Cronico," a chronicle appended to the history, begins with Arcadio Augusto's rise to emperor in $400 \mathrm{CE}$, and $407 \mathrm{CE}$ marks the first origin of Venice with the arrival of the Goths. He places the second origin of Venice at Alarico's sack of Padova that sends the Venetians fleeing to the lagoon in 412 CE. Still, following the legend of Venetian foundation on the Annunciation, he only begins counting Venetian years in $421 \mathrm{CE}$, when the Church of S. Iacomo is founded and consecrated in Rialto on 25 March. Sansovino, $24^{\mathrm{v}}-25^{\mathrm{r}}$; D. Rosand, 6-46. 
reprint of Sansovino's Venetia, Father Giustiniano Martinioni updated the chronicle to include events that occurred from 1580 to the present. Yet he ignores Galileo in both the chronicle and an accompanying table of local men of letters, due either to Galileo's Tuscan origins, his place on the Index of Prohibited Books, or his defection to Florence.

These various histories share with Strozzi's Edificata the purpose of preserving the image of Venetian glory in the face of signs that the Serenissima's prestige was waning. The myth of Venice was emphasized to remind both citizens and foreigners of the political and historical traditions that had made the republic endure. ${ }^{16}$ The Huns, Goths, and Vandals in the poems were frequently compared to the invading forces of French King Charles VIII in the late fifteenth century and Holy Roman Emperor Charles V in the sixteenth. Longstanding tensions with the Ottoman Turks, recurring conflicts with the pope, war in Friuli with the Austrian Habsburgs (1615-17), and growing suspicion about the ability of government to function well or justly had all taken their toll. ${ }^{17}$ Accordingly, modern historians have identified the growth of a cultural counter-current by 1620 , the anti-myth of Venice. ${ }^{18}$ Strozzi does not fall in with this anti-myth, and in the face of growing anxiety about Venice's decline in the first decades of the seventeenth century, he participated in the widespread poetic effort that asserted the republic's continuing strength, individuality, and independence. Like many, he dwelled on early victories as a means of avoiding mention of recent defeats. ${ }^{19}$ His account of the foundation of Venice closely followed the fifteenth-century chronicler Paolo Morosini (1406-83), whose Historia della città e Republica [sic] di Venetia ended in 1483 (the year of his death) and was still being reprinted without additions or appendices as late as $1637 . .^{20}$

Strozzi was not the only poet to follow Morosini. He was, however, the only one who wrote sustained meditations on Galileo's contributions to natural science and philosophy. Other poets used their license to interpret the foundation of the city loosely, and included astrological frameworks in

${ }^{16}$ Vivo, $148-56$.

${ }^{17}$ Bouwsma, 52-59, 88-93.

${ }^{18}$ Vivo, 252-53.

${ }^{19}$ Muir, 1981, 13-74.

${ }^{20}$ Morosini recounts Honorio's victory over the Huns and Vandals in $406 \mathrm{CE}$, and the sack of Rome by Alarico and the Huns in $410 \mathrm{CE}$. He marks this as the moment when citizens of the Veneto retreated to the lagoon to escape the cruelties to which they were being subjected. He mentions Attila's siege of Aquileia specifically as a motivator for residents of various cities to take up residence on specific islands of the lagoon (for example, the Padovans who retreat to Rialto): P. Morosini, 3. 
which references to Galileo or cosmography more generally would have seemed natural, even necessary. Ferrante Pallavicino's Panegirico (Panegyric, 1649) for Venice, subtitled "Il Sole ne Pianeti, cioè la Grandezza della Repubblica" ("The Sun among the Planets, that is, the Grandness of the Republic"), praised Venice (the Sun) astrologically, that is, according to her relationship with the other planets. So, for example, Venice's relationship to Saturn showed her nature as a republic, and her position relative to Mars showed her military strength. Pallavicino came closest to an allusion to Galileo in his mention of a lynx-like eye, an "occhio per Linceo," that cannot find a single defect in Venice's beauty. This could be a reference to the Accademia dei Lincei, which supported Galileo when he was challenged for discovering the so-called imperfections on celestial bodies that had previously been considered flawless. ${ }^{21}$ Yet Pallavicino gives no clear allusion to Galileo or his ideas, and, in fact, citing the sharp eye of the lynx was a common convention used to represent keen observation. One of Galileo's friends, Ottavio Livello (d. 1631), wrote his own Concettione di Venetia (Conception of Venice, 1624), charting the history and future of Venice by astrological markers. ${ }^{22}$ Livello takes an obvious anti-Rome stance and begins his history sixteen centuries before the arrival of Attila in order to demonstrate Venice's longstanding independence from the Roman Empire, yet he makes no mention of Galileo, suggesting that, notwithstanding their personal friendship, Galileo was not considered to be part of Venetian history as such.

Cesare Cremonini, a prominent figure in Venice who was also a close, yet skeptical friend of Galileo's, also failed to mention the Tuscan scientist. Cremonini was a prominent and very well-paid professor at the University of Padua, and the most famous person to refuse to look through Galileo's telescope. ${ }^{23}$ Cremonini's students founded a prolific cultural group, the Accademia degli Incogniti, that was openly skeptical of received tradition; Strozzi himself was a member. ${ }^{24}$ Drawing on patriotic sentiments expressed in the early days of the conflict with the Jesuits in Padua, Cremonini published his own version of the Venetian foundation myth: Il Nascimento di Venetia (Birth of Venice, 1617). This four-act piece reads more like a pastoral than a work of mythology, yet Cremonini mentions in his introductory letter to the reader that he aims to achieve through it the successful marriage of poetry and philosophy. In the Nascimento the city is founded by a son of Neptune, the principal activities take place on or under

\footnotetext{
${ }^{21}$ Pallavicino, 58.

${ }^{22}$ Livello, A3 ${ }^{\text {r }}$; Galilei, 1964-66, 12:118-19.

${ }^{23}$ Cremonini was the professor whose salary Galileo envied: Heilbron, 64-65, 195-96.

${ }^{24}$ Muir, 2007, 22.
} 
the water, the protagonists are fishermen, and sea monsters create the dramatic interludes in the acts. Significantly, there is no discussion of tides in the work, despite this having been a very current topic in philosophy lectures in Padua and something that had found its way into several other poetic pieces at the time, thanks to the circulation of Galileo's letter known as the Discorso sul flusso e reflusso del mare (Discourse on the Tides, 1616). Galileo seems to have noted the silence. When he later elaborated on these ideas about tides in the Dialogue on the Two Chief World Systems (1632), published shortly after Cremonini's death, he included an Aristotelian interlocutor Simplicio, whom many readers recognized as a portrait of Cremonini himself. ${ }^{25}$

Cremonini was frequently obscure or indirect when dealing with the larger philosophical debates of the day in his poetry. His Nascimento marries poetry and philosophy but is silent on some matters of controversy with which he was directly involved at the time. ${ }^{26}$ The opening lines of the final Chorus drive home the point that Cremonini is talking about a geocentric universe. He says that an intellect that sees the heavens in motion cannot be wrong, and he plays on the double meaning of the Italian verb errare: "Like in the heavens, that, seen by that intellect / erring, cannot err." ${ }^{27}$ In the verses that follow this declaration Cremonini even includes a reference to the calculations being made of the observations of the night sky and the appearance of new stars. Yet he situates this discussion in the context of a more metaphorical discussion of the shape and place of Venice in a geocentric system. ${ }^{28}$ Cremonini's principal task is to glorify Venice over all other republics. While this is quite similar to Strozzi's goal, Cremonini resists making extended reference to current events and explicitly affirms the validity of philosophical tradition.

A more direct response to Galileo's studies came from Antonio Consalvi (fl. 1610-20), who explicitly warned about exploring the mysteries of the cosmos. His maritime fable, Il Consiglio delli Dei per la fondatione, e grandezza dellinclita città di Venetia (The Advice of the Gods for the Foundation and Greatness of the Noble City of Venice, 1614), tells the story of Neptune, who invites all of the gods except Cupid to join a council that will determine the shape of a new city, Venice. Cupid exacts his revenge by creating mayhem at the council, which is ultimately thwarted. Various

${ }^{25}$ Drake, $1978,335$.

${ }^{26}$ Muir, 2007, 15-59.

${ }^{27}$ Cremonini, 100, vv. 1-2: "Come nel Ciel, che, da tal senno è scorso / Errando errar non puote."

${ }^{28}$ Ibid., vv. 3-12. 
episodes show some of the deities scrutinizing the inner workings of the cosmos. Vulcan asks Jupiter why he permits such ruin on earth to come from the heavens, and Jupiter responds:

Now be quiet, and put to rest your clouded and no less curious mind, and do not wish to know beyond that which is appropriate for you and is meant for you "Because he who wants to ascend from heaven to heaven, and ambitiously climb over the walls of the universe, and, full of arrogance, look in the face of the Highest Eternal Good, almost like a new Icarus in the Aegean, careless, drowns by his own desire."

It is unclear what source Jupiter might be citing in the last lines of his reply to Vulcan, but the purpose of drawing on Icarus for the moral is clear: observe from a distance and do not presume to draw conclusions. Jupiter equates himself with the sun. He warns Vulcan, the supreme artisan, not to look the sun in the face. Even though there are no direct allusions to Galileo in this work, Consalvi's tone suggests that no good can come from making new discoveries in the heavens and questioning the ordering principles of the cosmos. No figure like Galileo intercedes in these stories, but this systematic denial (or omission) suggests that his discoveries were making an unwelcome impact that made many anxious. Almost all poets who covered the myth of Venice at this time ignored Galileo. Even those who were close friends ignored or warned against participating in the kinds of controversial debates in which Galileo engaged, suggesting that many saw his impact as negative.

\section{Galileo in Poetry: From Guest appearances TO RECURRING ROLE}

Galileo's ideas appeared more frequently in poetry elsewhere, particularly as his ideas became more controversial. His move to Florence brought him into an intellectual territory where some poets even included disclaimers that their representations of celestial bodies were not meant to offend Church

${ }^{29}$ Consalvi, 57-58: "Hor quì s'acqueti adunque e quì si posi / L'offuscata non men, che curiosa / Tua mente, nè desii saper più oltre / Di ciò, che le conviene, e se le aspetta: / 'Che chi poggiar ne vuol di Cielo, in Cielo, / E sormontar le mura ambitioso / De l'universo, e pieno di arroganza / Mirar in faccia il sommo eterno bene, / Quasi Icaro novel ne l'Egeo al fine / Negletto si sommerge entro al suo ardire."” 
dogma. ${ }^{30}$ Once reestablished in Florence, he occupied himself with lengthy debates on tides, floating bodies, sunspots, and comets. The result of one of these debates was his Lettera a Madama Cristina di Lorena Granduchessa di Toscana (Letter to the Grand Duchess, 1615), the lengthy missive that circulated among pro- and anti-Copernicans alike, and in which Galileo attempts to reconcile biblical exegesis with the heliocentric theory. The response of Cardinal Bellarmine that Copernicanism could be used as a mathematical tool for astronomical predictions, but only if treated as a theory and not a fact, limited marginally the spread of Galileo's ideas in popular culture. Since Florence had a more closely regulated publishing environment than Venice, Galileo and his publishers needed to comply with the ruling; the greater freedom in Venice permitted Strozzi to address these issues in his works. Galileo's popular reputation grew nonetheless, particularly outside of Italy.

By the time of the first edition of Strozzi's Edificata in 1621, Galileo and his more novel ideas had already appeared in numerous works of poetry, both in Italy and beyond. Galileo himself recruited poetic pieces in praise of the telescope and the Medicean stars for the never-published second edition of the Starry Messenger. ${ }^{31}$ References both supportive or critical are typically in single sentences that mention the telescope or the selfproclaimed philosopher without much further integration of either into the text, and also without direct reference to Galileo's publications. The first clear literary reference was actually in English rather than in Italian, and was hardly flattering. In John Donne's 1611 work Ignatius His Conclave, or His Enthronization in a Late Election in Hell, Galileo, Copernicus, Machiavelli, Paracelsus, and Ignatius of Loyola compete for the seat next to Lucifer. ${ }^{32}$ More notably, John Milton's later program of experimental poetry owed its optics to the telescope and to Galileo, who is the only contemporary Milton identified by name in Paradise Lost (1667). ${ }^{33}$ Milton also refers to the "Tuscan artist" who observes the moon, and describes Satan as a "spot like which perhaps / Astronomer in Sun's lucent Orbe / Through his glaz'd Optic Tube yet never saw." The Angel Raphael's flight among the heavenly bodies is also linked to the revelations of the telescope. ${ }^{34}$ Both Donne and Milton refer to the historical figure of Galileo, which is quite different from the fictionalized accounts of the telescope's creation, use, or reception that can be found in Italian poetry of the period.

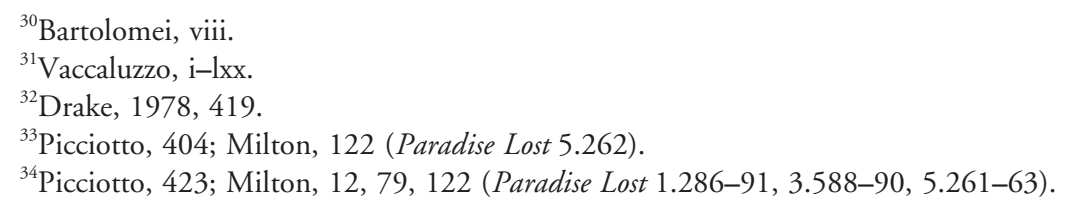


In Italian literature, allusions typically appear only in later decades. Diverse figures foretell the advent of the telescope in some early and midseventeenth-century poems, as, for example, a magician in the Vittoria navale (Naval Victory, 1646) by Guidobaldo Benamati of Gubbio (d. 1653) and an angel in Malatesta Porta's epic poem about his native city, Rimino protetto (Rimini Protected, 1628). ${ }^{35}$ These are simply two of many examples of the historical invention of the telescope being recast into fictionalized settings. ${ }^{36}$ The telescope also frequently appears as a tool of voyeurism, for example, in the Cunto de li cunti (The Tale of Tales, 1634) by the Neapolitan Giambattista Basile (1575-1632) and in the Rime (1689) of the Venetian Bartolomeo Dotti (1651-1713). ${ }^{37}$ In the posthumous Contro la lussuria (Against Lust, 1686) by Lorenzo Azzolino (d. 1632) from Le Marche, the telescope becomes an instrument for flirting: "Who needs an internal room or harem / since in order to play the coquette all the way to the rooftops, / Galileo has found the method." 38 These allusions to Galileo in the poetry of the period show how the philosopher, his inventions, and his subsequent discoveries caught the imaginative attention of seventeenth-century authors, who then used them in various contexts. Still, each mention constitutes merely a phrase, a poetic line, or a stanza.

Not all allusions in Italian literature are as superficial as these. Some authors ventured further in their presentation of Galilean discoveries, seeking to instruct readers with anachronistic presentation of current events in scientific debates. Some supported Galileo's arguments and others did not. In his epic America (Rome, 1650), the Florentine musician Girolamo Bartolomei (1584-1653) included over fifty octaves on Amerigo Vespucci sighting sunspots and learning about the composition of the universe in the fifteenth century. Like Strozzi, Bartolomei benefited poetically from an early acquaintance with Galileo, and his work was introduced to the Austrian court thanks to Galileo's intercession. ${ }^{39}$ In his Venetia libera (Free Venice, 1622), Camillo Pancetti da Serravalle followed Paolo Morosini's account of the foundation of the city, as Strozzi did, and the hero of his poem learns about the movement of the earth and tides from a hermit in the ninth century. ${ }^{40}$ The hermit even digresses into a discussion of tides,

${ }^{35}$ Vaccaluzzo, 53, 85.

${ }^{36}$ Many similar examples are found in English poetry of the period: Reeves, 162-66.

${ }^{37}$ Battistini, 38.

${ }^{38}$ Camporesi, 103: "Che vale interna stanza, o gineceo? / Poiché per civettar fin da l'altane / Ha ritrovato il modo Galileo."

${ }^{39}$ Galilei, 1964-66, 17:27, 253-54, 323, 326-27; Hill, 131.

${ }^{40}$ Pancetti da Serravalle, 2.74 . 
although he emphasizes repeatedly that the heavens move and the earth remains at the center of their motion. ${ }^{41}$ Later he explains that comets are the result of hot vaporous exhalations, something against which Galileo argued vehemently in the Saggiatore (Assayer, 1623). ${ }^{42}$ Venetian poet Lucrezia Marinelli (1571-1653) frequently included references to topics of current scientific debate in her works, describing the movements and functions of celestial bodies, supporting the idea that the substance of the Milky Way is a collection of stars, explaining eclipses, and commenting on the cause of the tides. Yet she concluded these didactic asides with assurances to the reader (and to the censors) that the sun moves around the earth. ${ }^{43}$

Even Giulio Strozzi himself does not consistently adopt the proCopernican stance that he takes in the Edificata. In the Delia (1639), a narrative replete with references to celestial bodies that include the sun taking human form, Strozzi maintains strict adherence to both the Ptolemaic system and an allegorical presentation of the Truth (Sole) descending to mankind in the form of a wise prince who marries Knowledge (Delia). ${ }^{44}$ And in the second act of his play the Finta savia (1643), characters argue over the various astrological interpretations of a comet with no mention of the debates among astronomers on the substance or origin of comets. ${ }^{45}$ It may be significant to note that both these works were published much later, the first while Galileo was under house arrest and the second after he had died. Clearly his value as a poetic commodity was not what it had been in the first quarter of the century. Yet Galileo's philosophical prose inspired and continued to inspire creative and critical pairing of epic poetry with the new science, which speaks to the subtle ways that the philosopher evoked and incorporated the genre with his own work, something that Strozzi attempted to harness throughout several of his texts. ${ }^{46}$

${ }^{41}$ Ibid., 15.12-13

${ }^{42}$ Ibid., $15.75-76$.

${ }^{43}$ Marinelli, 5.90.5-6, 13.57.1-2.

${ }^{44}$ Strozzi, 1639, 10.

${ }^{45}$ Ibid., 1643, 129.

${ }^{46}$ The relationship between Galileo and the genre of epic poetry or prose has even persisted into modern scholarship on the Tuscan philosopher. Galileo's most recent biographer, J. L. Heilbron, calls Galileo's period in Rome in 1611 "knight-errantry" and his 1623 work on comets "a heroic poem in prose." In his presentation of the years surrounding the publication of Galileo's Dialogue on the Two Chief World Systems (1632), Heilbron divides the chapter into the following subheadings: "The Knight," "The Windmill," and "The Tilt." According to Heilbron's quixotic theme, Galileo is the knight, the pope the windmill, and the Chief World Systems the tilt: Heilbron, 208-12, 245, 257-95, 296-317. 


\section{StrozZi's Early Commitment to The GALILEAN PROJECT}

In contrast to the brief allusions to Galileo in most poetry of the period, Giulio Strozzi made Galilean science structurally essential to the Edificata. His desire to incorporate Galilean themes in his poetic corpus can be seen in several of his earlier works, and to a lesser degree in the theatrical pieces written after the Edificata. Strozzi was present in Rome when Galileo demonstrated sunspots to a number of prelates and cardinals just two years prior to publishing the Edificata. ${ }^{47}$ In the Erotilla (1615), written for the marriage of Marc Antonio Borghese and Camilla Orsini, the main female character is frustrated with having to continually prove her love to the male hero and asks what she is supposed to do if he insists on searching for imperfections in her spirit: "Poor me, for what else can I hope, what else can I attempt / to make you certain again of my faithfulness? / If you try to find spots on the sun, / if you don't look at the effects and you don't measure / love with deeds?" ${ }^{48}$ Sunspots were intensely discussed among Galileo's followers and detractors alike, particularly following the publication of the 1612-13 debate with Christoph Scheiner. Erotilla's question moves the physical discovery of dark spots on the sun into a realm of emotion and human interaction. Just as the telescope was not fixed as an instrument solely for celestial observations, so the debate on the nature of sunspots expanded from its philosophical and physical implications to a metaphor for the difficulties of romantic relationships.

While there is no extant correspondence between Galileo and Strozzi, the Venetian poet's early praise of the Medici is seldom without reference to the Pisan philosopher under their patronage. In the funerary Oratione (1621) for Cosimo II, the author combines praise of the Medici with the praise of Galileo, a poetic recipe seen also in the Edificata. Strozzi mentions the presence of Galileo at the Medici court, but he does not use the philosopher's name explicitly. He speaks instead of the Medicean stars: "the four planets that are loyal courtiers of Jupiter, so much so that the industrious inventor of the instrument was obliged to consecrate his discovery to the greatness of Cosimo, not without result, so that now one can recognize them in the heavens with the most serene name of Medicean stars, and predict their paths in our Ephemerides, which in part imitates the custom of talented antiquity, which under the images of stars placed up there in the

${ }^{47}$ Galilei, 1964-66, 5:82, 19:612.

${ }^{48}$ Strozzi, $1615,101^{\mathrm{r}-\mathrm{v}}$ : "Misera, à che più spero, à che più tento / Di farti certo ancor della mia fede? / Se cerchi macchie indovinar nel Sole, / Se non miri à gl'effetti, e non misuri / L'amor con l'opre?" 
heavens the names of the most esteemed heroic souls through fables." ${ }^{49}$ Strozzi makes sure to mention Galileo's reward in the form of appointment as court philosopher and mathematician to the Medici. Galileo too had been specific about wanting to follow ancient tradition, saying in the preface to the Starry Messenger that a "noble and admirable" custom had placed "pristine heroes" among the stars before the practice fell into disuse for centuries. ${ }^{50}$ Just as Galileo had reiterated his praises of the Medici to Cosimo II after the death of his father Ferdinando I, so Strozzi repeated his overtures to the Medici court to Ferdinando II after the untimely death of Cosimo II. His praise of the Medici was far from coincidental, being instead part of a decade-long program to gain their attention and earn their esteem and patronage.

In what appears to have been an attempt to follow Galileo and move from the Veneto to Tuscany, Strozzi invested considerable poetic effort into continuing his praises of the Medici family. The complexity of the network of notoriety involved in patronage at the time can be seen in the negotiations of Michelangelo Buonarroti, Jr. (1568-1646) acting as a broker in Florence for Maffeo Barberini in Rome when Barberini attempted to draw Galileo to his court. ${ }^{51}$ All of the agents in a patronage system stood to gain something for their efforts. The question remains as to what Strozzi had to offer to the Medici. His general ambition is most evident in the changes made to the prefaces of the Edificata between the 1621 and 1624 editions, but what in particular he may have been seeking remains obscure. The early, incomplete edition of the poem is dedicated entirely to the Serenissima and to the doge. In the 1624 edition, Strozzi shortens this dedication to a single sentence. It is, admittedly, a lengthy one that lists twelve laudatory periphrases for Venice, five adjectives to describe her virtues, three actions Strozzi hopes to complete by publishing the work, and two descriptors of his devotion. ${ }^{52}$ The

\footnotetext{
${ }^{49}$ Strozzi., 1621a, 23v: "i quattro Pianeti assidui Cortigiani di Giove, acciòche l'industrioso inventore dovesse alla grandezza di Cosimo, non senza frutto, il suo ritrovamento consacrare, onde si possa col Serenissimo Nome di Stelle Medicee etername(n)te in Cielo riconoscerli, e nelle nostre Effemeridi annoverarli: Imitando in parte il costume della dotta antichità, la quale sotto imagini di Stelle le anime de' più pregiati Eroi lassù favolosamente riponeva."

${ }^{50}$ Galilei, 1989, 30 .

${ }^{51}$ Cole, $729-88$.

${ }^{52}$ Strozzi, 1624, $2^{\mathrm{r}-\mathrm{v}}$ : "To the immortality of the name of the Most Serene Republic of Venice, heir of ancient valor, bastion of Italy, ornament of Europe, marvel of the universe, support of the Christian religion, firstborn of the Holy Church, oracle of all princes, splendor of all centuries, sower of indomitable heroes, chamber of true liberty, most glorious in peace, strongest in war, always magnanimous, always felicitous, and always just, the humble servant and admirer of so many virtues, Giulio Strozzi, reverently offers, donates, and consecrates this brief compendium of Venetian praises."
} 
stylized euphemisms of the earlier dedication are entirely replaced by a checklist that ensures the satisfactory, and perhaps gratuitous, dedication of the poem to its subject.

Following this single sentence dedicating Venetia edificata to the Venetian republic, Strozzi turns his attention to the new dedicatee of his poem: the Grand Duke of Tuscany, Ferdinand II. The motives for Strozzi's presentation of a work that praises Venice to the man who represented the cultural and political ambitions of Tuscany are unclear. Strozzi does not address this directly, and may simply have been negotiating the politics of censorship. Given Venice's looser application of censorship restrictions, it was easier to publish there a work speaking of Galileo's value to the intellectual community generally and glorifying the support and involvement of his Tuscan patrons. ${ }^{53}$

That said, it is hard to miss the evident conflict between the original dedication of his incomplete work to the Republic of Venice in 1621 and the very lengthy direct letter to Ferdinand II that dwarfs all other prefatory material in the finished poem of 1624. The deliberate search for patronage provides the most likely reason for this contrast, and Strozzi's rhetoric follows all the conventional formulas of courtier-patron interactions. After the flattering captatio benevolentiae in his letter to Ferdinando II, Strozzi announces: "I undertook to wander in this project at my own expense, and I wanted to be seen more as an unhappy discoverer than a furtive copier of things that have already been said." "St Strozzi does not indicate what his expenses were, leaving the presumed future patron to imagine either mental toil or publishing expenses incurred when the premature release of the first twelve cantos in 1621 failed to raise the necessary capital for the 1624 complete edition. Strozzi includes a lengthy explanation of the dire straits in which he was living while finishing the Edificata: "I can call this birth the son of my pain, since I put the finishing touches on him while I was occupied in quarrelsome uproars, and my desire to serve such gracious patrons had greater power over me than the affliction caused by threat of disaster. This should serve as an excuse for me, if the rhyme is seen to run without its usual felicity, which it ought to do; since I was overcome with domestic concerns, I was halted frequently in the course of my public praise." ${ }^{55}$ Strozzi may have

${ }^{53}$ Grendler, 274.

${ }^{54}$ Strozzi, 1624, $3^{\text {r }}$ : "Hò procurato d'errare in questo a mie spese, ed hò voluto esser reputato più tosto infelice ritrovatore, che furtivo Copiatore delle cose già dette."

${ }^{55}$ Ibid., $3^{\mathrm{v}}$ : "Io posso chiamare questo parto figliuolo del mio dolore: poiche gli hò data l'ultima mano frà litigiosi strepiti occupato, ed hà potuto più in me il desiderio di servire a sì cortesi padroni, che l'afflittione delle minacciate calamità. Ciò mi servirà per iscusa, se tal'hora si vedesse correr la rima non con quella felicità, che doverebbe; poiche soprafatto da' pensieri domestici, io mi arrestava bene spesso nel corso delle pubbliche lodi." 
been living in Venice while he was writing, but the city was not yet rewarding him well for his poetic efforts. The Edificata accordingly became an attempt to curry the favor of a new patron from a family that had already demonstrated its interest in scientific curiosities and its beneficence toward the purveyors of these new ideas by making Galileo Galilei a member of their court. A closer examination of the poem shows how this strategy shaped its composition.

\section{SUBTEXTS FOR VENETIA EDIFICATA}

The Venetia edificata follows many of the poetic patterns established by Strozzi's contemporaries, both those who were trying to reinforce the myth of Venice and those who were trying to incorporate the new science into their work. Modern criticism mentions the connection of Galileo's ideas with Strozzi's poem, but provides no analysis of the poetics or intertextuality at work in its composition. ${ }^{56}$ By the time the definitive edition of the Venetia edificata was published, Galileo had been living in Florence for over thirteen years. Strozzi's poetic program was more ambitious than the usual brief mention of the telescope, the Medicean stars, or the controversy surrounding heliocentrism. ${ }^{57}$ Some of the authors whom Strozzi assembled to include prefatory poetry for the Edificata were also active in the field of natural philosophy and were famous for their work. Cristoforo Ferrari (fl. 1600-30) had some familiarity with Galileo, having sent the philosopher poetic compositions via a friend and then having written to him directly in $1612 . .^{58}$ The conservative thinker Andrea Chiocco (1562-1624), who includes a poem of praise for Ferrari, gave a series of public commentaries on Plato and Aristotle, specifically the De meteore; published a catalogue for Francesco Calzolari's museum of natural science; and also wrote the "Discorso sulle apparenze solari" ("Discourse on Solar Appearances"), an unpublished treatise on sunspots that likely contested Galileo's own interpretations of the phenomenon. ${ }^{59}$ Christoph Scheiner lists Chiocco as one of many "earwitnesses" to the controversy on sunspots, suggesting that he had not used a telescope to become an eyewitness. ${ }^{60}$ Galileo and the investigations around his work permeate the Edificata to an extent far beyond that of any other contemporary poetic works that include references to his ideas.

\footnotetext{
${ }^{56}$ Most recently, Heilbron, 229.

${ }^{57}$ Spiller; Dick.

${ }^{58}$ Galilei, 1964-66, 11:367, 504.

${ }^{59}$ Dizionario biografico degli italiani, 25:11-12, "Chiocco, Andrea."

${ }^{60}$ Galilei, 1964-66, 5:62; Galilei., 2010, 219-20.
} 
In his preface to the 1621 edition of the Edificata, Strozzi had projected eighteen future cantos to complete the work. The poem in its final 1624 version consists of twenty-four cantos ranging from seventy-five to 109 octaves in length. ${ }^{61}$ In the earlier edition many of the cantos are shorter, appear without the prose argomento or a summary octave, and lack illustrations. In the completed text, Strozzi added an entire canto of episodes involving almost every major character to the first part. The principal characters in the story perform the usual dance of misadventure, disguise, outright deceit, and revelations of secret identities. The unifying action of the various episodes in the poem is the foundation of Venice based on a celestial image seen by the allegorical figure of Art in the year $453 \mathrm{CE}$. The Medici even make their way into this scene when Lady Art receives a prophetic vision of "the friendly alliance with the Tuscans" led by Cosimo de' Medici. ${ }^{62}$ She is moved to her act of creation by the years of war and turmoil that have destroyed all of the city's original artistic and architectural beauty. The most recent assault was sparked by the second descent of Attila, King of the Huns, into Northern Italy to pillage, plunder, and conquer, and to claim his bride Onoria. Onoria was the sister of the Holy Roman Emperor Valentian III, who vehemently opposed the union. Through various machinations, imprisonments, elaborate escapes, botched getaways, cities besieged, cities liberated, battles in mountain passes, conflicts at sea, duels, suicides, partisan politicking, miraculous visions, and wizardry, the physical edification of Venice is finally achieved and a host of evil characters lies defeated, dead, or dying at the feet of the noble and morally edified Venetians.

This would seem a strange narrative setting for a character based on Galileo and his discoveries. Nonetheless, Galileo appears in the seventh canto as the English wizard Merlin, who aides in the liberation of Aquileia. In the context of the poem, this is the third time readers have seen the siege of Aquileia. In the woodcut that opens the canto (fig. 1), the foreground shows a separate event that takes place in the Venetian tribunal. On the battlefield surrounding the city walls are the Roman forces attempting to liberate the city; across the lagoon the Huns are defending a tower. At the top of the makeshift Roman tower at the center, the illustrator, Valesio, has indicated "Oddo con l'occhiale" ("Oddo with the spyglass"), peering into the besieged fortress at the center of the city. Although Galileo is not mentioned by name, there can be no misinterpretation about the inspiration for the Merlinfigure. "Merlin Anglo" gives the Frankish warrior Oddo the "wonderful and divine instrument / that brings a distant object close" in order to better

\footnotetext{
${ }^{61}$ Strozzi, 1621b, i.

${ }^{62}$ Strozzi., 1624, 11.53.1-4: "Ecco de’ Toschi l'amichevol Lega."
} 
observe the movements of his enemies, Attila and the Huns. ${ }^{63}$ In the 1626 reedition of the Venetia edificata, published in duodecimo, the woodcuts are slightly different, and signed by a different artist. The opening scene for canto 7 still identifies Onoria and Anicetta at the Tribunal in Venice, but all labels are removed from the scenes in the background. In the far left background three men stand atop a tower, one directing a tube-shaped object toward the image of Aquileia besieged. In the center background three men fight one another, two men wander inside the walls of Aquileia on the right, and in the far background stands a group of soldiers. ${ }^{64}$

Near the middle of the preceding canto, Strozzi provides the description of the character who will become a key figure in the liberation of Aquileia, Oddo the Frank, a symbol of the enemy's ferocity and Roman tenacity. Oddo lost an eye in battle before being taken as prisoner of war in canto 5; after the Huns blind the remaining prisoners of war, Attila chooses him to lead his compatriots back to the Frankish camp in canto 6. Not by chance, the one-eyed leader of a thousand blinded men will come to possess the telescope, a gift from Merlin. Strozzi emphasizes the importance of Oddo's single eye for his selection as the owner of the miraculous instrument: "And if in one eye the knight is blind / that was the reason for calling him forth." ${ }^{65}$ As a reward for his strength, Merlin gives Oddo a new weapon of war, the form of which is unmistakable as the telescope:

It has the form of a horn and a length of two

cubits it extends; at the double holes

two glasses sit, the one in its convex curves

forms the beautiful work in the concave curves of the other.

The eye is placed close to the concave; and then they show,

where you point them, their effects

and to make close a very distant object

with immense magnification is the result. ${ }^{66}$

Strozzi's verses mirror the original ordering of the Latin phrases in the opening pages of the Starry Messenger in which Galileo describes his early

${ }^{63}$ Ibid., 7.49.7-8: “istromento mirabile, e divino / Che l'oggetto lontan porta vicino."

${ }^{64}$ Strozzi., 1626b, 190.

${ }^{65}$ Strozzi., 1624, 7.49.3-4: "E se d'un'occhio il Cavaliero è cieco, / Tal del chiamarlo fù l'alta cagione."

${ }^{66}$ Ibid., 7.50.1-8: "Forma hà di tromba, e di lunghezza in duoi / Cubiti si distende; al doppio foro / Due vetri stan; l'un ne' convessi suoi / Forma l'altro nel cavo il bel lavoro. / L'occhio al cavo s'accosta, e mostran poi, / Dove li fissi tù, gli effetti loro: / E d'appressar' ogni lontan' oggetto / Con moltiplico immenso è il lor effetto." 
model of the instrument. ${ }^{67}$ The original Latin syntax of the passage is maintained here in the English translation of Galileo's account of building his first telescope: "And first I prepared a lead tube, in whose ends I fitted two glasses, both plane on one side while the other side of one was spherically convex and of the other concave. Then, applying my eye to the concave lens I saw objects satisfactorily large and close. Indeed, they appeared three times closer and nine times larger than when observed with natural vision only." 68

Strozzi's presentation follows the text of Galileo's Sidereus nuncius line for line, except for using a musical term, tromba, to describe what Galileo calls simply a tubum. ${ }^{69}$ First, Galileo describes the tube, then the location of the lenses, followed by the convex lens, the concave lens, at which end the eye is placed, ending the sentence with a description of the magnifying effects of the instrument. Strozzi provides a level of detail that indicates significant familiarity with the text of the Sidereus nuncius, and not simply a general secondhand awareness of the story of Galileo and the telescope. He includes the approximate length of the telescope, two cubits, a detail that was not present in the Sidereus nuncius and would likely not have been part of hearsay about the instrument.

Strozzi adopts not only the text of the Sidereus nuncius, but the qualities of the telescope as well, to reinforce the distinctions between the heroes and the nefarious forces working against them in the structure of the poem. The helpful magician Merlin's refractive instrument of the new philosophy stands in direct contrast to the enemy sorceress Irene's traditional chamber of reflecting mirrors. Irene's mirrors are deceptive. They can change love into hate, and can multiply one image into several. Drawing an example from one of the most cited classical texts in seventeenth-century discussions of optics, Seneca's Natural Questions, Strozzi uses the images of the perversions of catoptrics to frame the enemy's technology: "The mirrors seem like those of Hostius Quadra and where they are laid out / they turn themselves into 100 other parts." ${ }^{, 70}$ The mirrors were crafted with the intent to deceive and the images they reflect become more lascivious, and of specious quality:

${ }^{67}$ On the origins of the telescope, see Van Helden, 22-28.

${ }^{68}$ Galilei, 1989, 37. The original Latin (in Galilei., 1993, 86) reads: "ac tubum primo plumbeum mihi paravi, in cuius extremitatibus vitrea duo Perspicilla, ambo ex altera parte plana, ex altera vero unum sphaerice convexum, alterum vero cavum aptavi; oculum deinde ad vavum admovens obiecta satis magna et propinqua intuitus sum; triplo enim viciniora, nonuplo vero maiora apparebant, quam dum sola naturali acie spectarentur."

${ }^{69}$ Galilei, 1993, 86.

${ }^{70}$ Strozzi, 1624, 20.13.7-8: "Sembra d'Hostio gli specchi: e dove stende / Altri se stesso in cento parti 'l rende." 
"Wherever you put your foot, the foot appears / clearly, and the mirror is such a happy painter / That he knows how to depict every resemblance in a lifelike way / And he makes it larger than the real one, and more lascivious." ${ }^{" 71}$ The visual trickery suggested by the mention of Hostius Quadra colors the passage with a morality counteracted by the virtues of Merlin and the telescope. ${ }^{72}$ As such, the Merlin-Galileo figure is a necessary structural element for artistic purposes, not simply a gratuitous mention of a figure from current events. Poetically, the known physical and scientific qualities of the telescope described in this canto become critical elements of the narrative and character development in the Edificata overall.

The similarities to Galileo are not only to be found in the description of the instrument, and go beyond the text of the Sidereus nuncius. Like many of the other magicians who appear with telescopes in the poetry of the period, Merlin can see the future, using a combination of his mind's eye and the eye of the telescope. Strozzi finds a creative way to explain Merlin's traditional foreknowledge in a way that emphasizes the telescope rather than the religious origins of his knowledge:

Here in a sacred shelter, the future

he predicts, and if much beyond he can make out with the eyes of the mind, then more surely to those of the senses he provides improvement. Since he is of a pure and perspicacious intellect, an emulator of Thales, in the end he realized that for such a noble sense he could with a little increase its value immensely. ${ }^{73}$

The topos of the eyes of the mind is particularly charged in the context of Galileo's thought as it had evolved through various publications. Much of Galileo's early work is based on the apparent discrepancies between phenomena observed with the eyes of the senses and those that are imagined with the eyes of the mind. Galileo speaks of the mind's eyes, what he calls the "occhi dello intelletto," in the Discourse on Floating Bodies (1612), and in the

${ }^{71}$ Ibid., 20.14.5-8: “Ove'l piede tù posi, 'l piede schietto / Appar', e tanto egli è pittor felice, / Che sà ritrarr'ogni sembiante al vivo, / E’l fà maggior del vero, e più lascivo.”

${ }^{72}$ Ibid., 7.51.1-8.

${ }^{73}$ Ibid., 7.52.1-8: "Quivi in sacro ricetto egli il futuro / Tal'hor prevede, e se tant'oltre ei scorge / Con gli occhi della mente, hor più sicuro / A quei del senso accrescimento ei porge; / Che d'intelletto perspicace, e puro, / Emolo di Talete, al fin s'accorge / Potersi di leggier sì nobil senso / Avvalorar d'accrescimento immenso." 
contemporaneous Letters on the Sunspots, written in 1612 and published in $1613 .^{74}$ The theme is also present in the Letter to the Grand Duchess, Galileo's attempt to reconcile biblical exegesis and the Copernican system, that circulated in 1615 , but was not published until $1636 .{ }^{75}$ This is a motif that persists through his other works, including the Dialogues on the Two Chief World Systems (1632). ${ }^{76}$ The other term that stands out in Strozzi's description is perspicacious, the adjective Galileo uses when praising intellects that most resemble his own, particularly in the Letters on Sunspots and the Discourse on Floating Bodies. ${ }^{77}$

Going several steps further than most of his poetic counterparts, Merlin repeats (or prefigures, in the context of the narrative) exactly what Galileo will do with the telescope while employed by the Venetian republic:

And, extracted from a most hidden rock layer,

he first grinds and smoothes the rough crystals.

Then on a solid adamantine stone,

he curves one out, and turns the other in.

And at the hour, in the season least hot, when the sky

abounds most with stars, least with vapors,

he looked for the reason why the silver moon

hides a part of itself that is concave and brown. ${ }^{78}$

Following the text of the Sidereus nuncius, this stanza provides the description of the general use of the telescope. After explaining its assembly, Strozzi mentions the best season for its use, winter, which corresponds to the season in which Galileo made the observations published in the Starry Messenger. In the treatise Galileo specifies the dates of his observations only when speaking about Jupiter and the Medicean stars, but using the information he provides about the moon, his lunar observations can be specifically dated as well. $^{79}$ Strozzi combines the inferred timing of the lunar observations with Galileo's famous presentation of the mountains of the moon in the first part of the book.

${ }^{74}$ Galilei, 1964-66, 4:81, 5:190.

${ }^{75}$ Ibid., 5:317.

${ }^{76}$ Ibid., $7: 169$.

${ }^{77}$ Ibid., 4:92, 5:186, 190, 198.

${ }^{78}$ Strozzi, 1624, 7.53.1-8: "E tratti fuor da più risposta falda / Rozzi cristalli, pria gli arruota, e monda, / Indi sù pietra adamantina, e salda / Incurva l'uno, e l'altro in giroaffonda. / E all'hor, che 'l Ciel nella stagion men calda / Di stelle più, men di vapori abbonda, / Mirò per qual cagion l'argentea Luna / Parte celi di sè concava e bruna."

${ }^{79}$ Whitaker, 159, 162. 
Strozzi then describes Merlin-Galileo's observations of Saturn, Venus, and the changes observed in the shape of the illumination of the stars as night progresses. The poetic description of these discoveries incorporates information Galileo published in 1615, five years after the images of the moon and the Medicean stars:

He saw Mercury and Venus grow as they moved and wane with double horn, and he burned with desire to discover adornments poorly seen in the luminous bearer of the day. Then above Mars he saw the unknown orbits and even Jove adorned by four stars that, wandering in the shortest interval, form around their great lord a dance. ${ }^{80}$

This stanza concludes with the most popular topic related to Galileo to appear in the poetry of the period: the discovery of the moons of Jupiter, which Galileo named the Medicean stars in the Starry Messenger. Yet Strozzi's presentation suggests a reading of more than Galileo's first text on celestial observations. Galileo circulated discoveries about the shapes of Saturn and Venus made in 1610 as anagrams in letters to friends, but did not publish them until the works on sunspots and floating bodies in 1612 and $1613 .^{81}$ The work on Mars was not published until Galileo's letters to Piero Dini and the grand duchess on biblical exegesis in 1615 .

Strozzi goes on to mention Galileo's observations of the myriad stars that make up the Milky Way and what he refers to as the moons of Saturn:

In three minor knots divided, he saw Saturn, and about the path that resembles milk and that is maybe the ladder to heaven, he defeats fantastic opinion. ${ }^{82}$

These so-called knots of Saturn, now known as the rings around the planet, were not mentioned until the Letters on the Sunspots. The composition of the Milky Way had been much debated, and Galileo's account of the

${ }^{80}$ Strozzi, 1624, 7.54.1-8: “D’Ermette vide, e di Ciprigna a' moti / Crescer' ambo, e mancar con doppio corno, / E di scoprir ardì freghi mal noti / Nel luminoso apportator del giorno. / Poi di Marte più sopra i giri ignoti; / E Giove ancor di quattro Stelle adorno, / Ch'errando con brevissimo intervallo / Formando intorno al lor gran Duce un ballo."

${ }^{81}$ Galilei, 1989, 102-11.

${ }^{82}$ Strozzi, 1624, 7.55.1-4: "In trè nodi minori egli diviso / Vide Saturno, e della via, ch'il latte / Pareggia, e scala è forse al Paradiso, / Le favolose opinioni abatte." 
recognizable stars within it, not an unknown celestial material, closed the controversy conclusively. ${ }^{83}$

Strozzi even recounts that Merlin-Galileo did not draw any conclusions from these observations at the time they were made, knowing people's reluctance to change the path of their gaze, not to mention that of their thinking:

He did not give notice of these great aspects at the time

since he well knew in that age

that people were not ready to raise so high

their sleepy minds along with their eyes. ${ }^{84}$

Strozzi continues his description of why Merlin-Galileo initially did not report his conclusions, a stanza that speaks to the core of Galileo's intellectual predicament once he had observed the moon with the telescope. He foresees:

That crude intellects can easily get lost in doubts and not resolve them; or that they will dismiss these new visions as trickery of the glass, or will not know how to receive them; or that we will set down such grand and poorly understood effects as the most fruitless of errors alongside the thinking that we circle around the sun on this terrestrial mass that is the center for the sun. ${ }^{85}$

He makes reference to the "crude intellects" that are not able to turn around in their minds doubts and new ideas. Rozzo (crude) is an adjective that Galileo uses infrequently but pointedly, once in the Letter to Castelli (1613) and once in the subsequent Letter to the Grand Duchess (1615), to denote the populace that needs the analysis of the Church Fathers to understand the truth of biblical passages. ${ }^{86}$ The verb raggirarsi, to wander around, is innate to the Aristotelian Peripatetics, whose name literally derives from the Greek

${ }^{83}$ Bucciantini, $176-77$.

${ }^{84}$ Strozzi, 1624, 7.55.5-8: "Non diede all'hor de' grandi aspetti avviso, / Che ben conobbe in quell'età non atte / A sollevar tant'alto esser le genti / Con gli occhi ancor le sonnacchiose menti."

${ }^{85}$ Ibid., 7.56.1-8: “Che di leggier potean rozzi 'ntelletti / Raggirarsi tra' dubbi, e non disciorli; / O che torrian questi novelli aspetti / Del vetro inganni, o non saprian raccorli: / O che sì grandi, e mal'ntesi effetti / In vanissimo error verriamo a porli, / Col pensar, che s'aggiri intorno al Sole / Questa, ch'è centro a lui Terrena mole.”

${ }^{86}$ Galilei, 1964-66, 5:282, 306, 316. 
term for "given to walking about." Strozzi's subsequent comment about the tricks of the telescope recalls Galileo's own friends' concerns about the veracity of the images seen with the telescope. Galileo's former colleague at Padua, Cesare Cremonini, supposedly declared the possible trickery of the instrument, and the mathematician Giovanni Antonio Magini expressed concerns about false reflections in the lenses. ${ }^{87}$ The final couplet also has thematic echoes with Cremonini's closing chorus from the Nascimento di Venetia, in which he declares that the mind cannot err if it sees that the sun does not wander.

Shortly after these stanzas, Merlin goes on to predict Galileo's reinvention of the telescope, a narrative move that avoids the question of primacy in the invention of the spyglass, one of Galileo's earliest disputes. ${ }^{88}$ Merlin foretells:

A time will come, when the Kingdom of Peter will see great Eagles allied with illustrious Dragons, when the most prized mind of Tuscany, renewing my illustrious glasses, and studies and the arts will be seen to re-flourish there in the region of Antenor. ${ }^{89}$

By setting this telescopic scene at a moment when an empire is in peril and by connecting the instrument to the glory of yet another regime, Strozzi doubly inserts himself in a literary tradition of optical devices that are pivotal to the idea of empire. ${ }^{90}$ Likely making reference to the contemporary conflict that would develop into the Thirty Years' War, Strozzi says that the pope (embodied by "the Kingdom of Peter") will see the eagles of German Protestant States allied with the English dragons in the first decade of the seventeenth century. Meanwhile, the territory of the Trojan hero Antenor, the Veneto, will bear witness to Tuscan Galileo's innovation, an invention that will impact all studies and arts. Strozzi hints at the coming of a prince who will know what to do with such discoveries - and it is not a Venetian but Ferdinand II de'Medici, the dedicatee of the Edificata, and Galileo's patron after he leaves Venice.

${ }^{87}$ Ibid., 10:442; Drake, 1978, 160; Biagioli, 2006, 15-85.

${ }^{88}$ Biagioli, 2010, 203-30.

${ }^{89}$ Strozzi, 1624, 7.57.3-8: “Tempo verrà, quando di Pietro il Regno / Vegga giunte a gran Draghi Aquile illustri, / Che dell'Etruria il più pregiato ingegno / I vetri miei rinovellando illustri, / Mentre, che rifiorir gli studi, e l'arti / Là si vedran nell'Antenoree parti."

${ }^{90}$ Reeves, 15-46, discusses this phenomenon in earlier poetic traditions. 


\section{A Response to Galileo's Criticism of Tasso}

A more subtle and telling use of Galileo's ideas comes when Giulio Strozzi incorporates into the Venetia edificata Galileo's corrections to Torquato Tasso's epic masterpiece, the Gerusalemme liberata. The issue here had to do with Galileo's ideas of verisimilitude in poetry, and the problem lay in Tasso's use of perspective. Strozzi wrote a series of octaves that followed Galileo's aesthetic principles as expressed in his private annotations of Tasso's poem and in letters to friends. Galileo's commentary on the Gerusalemme liberata, now known as the Considerazioni al Tasso (Considerations on Tasso), is extant only in one source, which is not an autograph series of annotations; he had not published anything on the poem before Strozzi incorporated his ideas into Venetia edificata. Nonetheless, his criticism of Tasso was not only well known, but also sought after by members of his intellectual circle. ${ }^{91}$ Galileo's earliest private correspondence on these notes on Tasso dates to 1609, well before he had contact with Strozzi in Rome. ${ }^{92}$ His commentary was part of the contemporary debate over Ariosto's and Tasso's muchdebated superiority to one another. Though not widely accessible, these notes circulated around a sufficiently large group to make his ideas generally known and even to generate rumors that pro-Tasso literary critics needed to publish quickly in order to beat Galileo's Considerazioni into print. ${ }^{93}$

Strozzi addresses the controversy in canto 7 when he engages with questions of visibility on the battlefield. The introductory summary to the canto gives the following description of the octaves dealing with the telescope, calling attention to Strozzi's narrative and poetic feat: "Aetio, grieving over the response from the Venetians, but more so seeing the advance the enemy made, directs the wondrous Spyglass, also called Telescope, given by the English Merlin to Oddo the Frank, in order to observe the activities of the enemy, where, with more than a little artifice, are reviewed the primary leaders of the Huns and the chief Dukes of Aetio's camp in a single narration." "This review of the enemy forces is an homage to the tradition of epic poetry, but one informed by the modern technology of the author's period. In what can be seen as a direct response to Erminia's

${ }^{91}$ Wlassics, 16-32.

${ }^{92}$ Galilei, 1964-66, 10:244.

${ }^{93}$ Unglaub, 116.

${ }^{94}$ Strozzi, 1624, 7: "Dolente Aetio della risposta de' Venetiani, ma più del passaggio, che faceva il nemico, si pone col mirabile Occhiale, detto Telescopio, dato da Merlino Anglo ad Oddo Francone, ad osservar l'opre del nemico, dove con non poco artificio si vanno rassegnando tutti i capi principali degli Hunni, $\&$ insieme i primi Duci del campo d'Aetio in una sola narratione." 
description of Goffredo's troops outside Jerusalem in canto 3 of Tasso's poem, Strozzi makes yet another push for the utility of the instruments of philosophy in a work of poetry.

Since Merlin has announced that the lenses will be destroyed in spite of all efforts for their preservation, Strozzi's Oddo uses the time that he has left to put the telescope to good use. He observes his enemies and sees through their trickery, and he graciously brings the instrument to other dukes for their use as well, since the images in the lens are assuredly reliable: "it will bring to them images that are not false." 95 The Huns cannot escape the gaze of the glass. Each Hun knight becomes entrapped by the instrument, a prisoner of magnification. The King of the Franks is the first to use the telescope, and plays out a ritual of the optical deception it produces:

close to the eye, and fully revealed,

he sees coming toward him Adimanto

and, losing control to his impetuous rage,

he grabbed his sword, then of such error

he became aware, so he took away from his eye

the occhiale and said: "What am I thinking, fool?"96

In the incomplete edition of the poem, canto 7 ends with the King's surprise that the telescope can convincingly show his enemy in such detail that he seems within a sword's reach. This common trope appears frequently in discussions of optics of the period. For example, the prolific Neapolitan Giambattista della Porta (ca. 1535-1615) devotes an entire chapter of his Natural Magick (1558) to "Strange Glasses," of which he says that the "lenticular crystal" will show things so near "that you will think you touch it with your hand." 97 Strozzi says only: "This vision of the troops of Attila will continue until the end of the canto, since the author judged it would be better to finish the work and then take the names from the rest of the poem." ${ }^{98}$ In the 1624 edition, after the King's gaffe, there follow nearly twenty stanzas that describe the Roman and Hun camps as seen through the telescope.

${ }^{95}$ Ibid., 7.59.6: "Porterà lor l'immagini non false."

${ }^{96}$ Ibid., 7.61.2-8: "Vicino all'occhio, e discoperto appieno / Vede incontro venirsi egli Adimanto, / Che sciolto all'ira impetuosa'l freno / Il ferro stringese poi d'error cotanto / S'avvide all'hor, che dall'un'occhio ei tolto / Il vetro, disse. E che presumo, o stolto?"

${ }^{97}$ Porta, 368.

${ }^{98}$ Strozzi, 1621b, 6.63: "Seguirà questa veduta di tutte le schiere di Attila fino alla fine di questo Canto, che hà giudicato l'Autore di mandar in luce li rimanente finita l'Opera, per poter meglio cavar dal corpo di tutto il Poema i nominati Guerrieri." 
The situation parallels the passage in Tasso's Gerusalemme liberata in which Erminia looks out upon the paladin forces from the walls of the besieged city and describes Saladin's enemies from her privileged outpost. The conversation between Aladino and Erminia reveals details about the characters in the paladin forces that provoke Galileo's ire. For example, from atop the walls of Jerusalem, Aladino asks Erminia about Goffredo and his brother Baldovino: “'Tell me,' he asked, 'who is that other man / standing in crimson by the conqueror? / How closely he resembles him."'99 Aladino can apparently recognize the facial features of the two men well enough to notice their relation. Galileo was heavily critical of the scene, saying in a marginal note to canto 3 of the Liberata: "If one goes about calculating well, this king and Erminia, at the top of a tower, could not have been less than a mile distant from the site where they were going about these motions of war, considering the retreat that the pagans make, stanza 31, and considering what is said in stanza $36 \ldots$ Nevertheless they had such perfect vision, that they recognized distinctly the Christian knights, even in the midst of the dust caused by the skirmish, which are things in our time that cannot be done even at the distance of an eighth of a mile. But let us be a little patient, because we will hear better before this king falls low." ${ }^{100}$ Galileo repeats his complaint in notes to stanzas 37 and 58, sarcastically commenting on the excellent vision of Aladino and Erminia. ${ }^{101}$ Heilbron has already connected Galileo's criticism of Erminia's spectacular, but not spectacled, vision to Galileo's larger concerns with verisimilitude. ${ }^{102}$

Strozzi rewrites this scene with the use of the telescope, effectively making the review of the Hun army more realistic to the reading audience. One of the frequent points of reference for scholars of optics, such as John Dee or Giambattista della Porta, was the power of refraction to make the faces and identities of one's enemies clear at long distances. ${ }^{103}$ Tasso's Erminia is replaced by the woman warrior Renea:

${ }^{99}$ Tasso, 3.61.3-5.

${ }^{100}$ Galilei, 1964-66, 9:85: “Se si va ben calculando, questo re e Erminia in cima d'una torre non potevano esser lontani dal luogo, dove si facevano questi fatti d'arme, manco d'un grosso miglio, considerata la ritirata che fanno i Pagani, st. 31, e considerato quel che si dice nella st. 36. . e nulla di meno erano di così perfetta vista, che riconoscevano distintamente i cavalier Cristiani, anche in mezo alla polvere della scaramuccia, che son cose che a'nostri tempi non si potran fare nè anche nella distanza d'un ottavo di miglio. Ma abbiamo pur un poco di pacienza $[s i c]$, che sentiremo di meglio, avanti che questo re cal abbasso."

${ }^{101}$ Ibid., 9:88, 91.

${ }^{102}$ Heilbron, 21, who lists the following locations of Galileo's criticism of verisimilitude in Galileo, 1964-66: 1.33, 5.92, 7.8-9, 14.31, 16.1, 37.

${ }^{103}$ Van Helden, 28-29, 34. 
And now on the third day, to the beautiful crystals

Renea places her eyes, eager to see

the chosen squires and the Hun horses,

of which their great King was more than a little satisfied.

And after long and noble intervals,

armed with scepter and dagger, the King arrived

surrounded by a thousand ardent warriors

who never tire or slow in following him. ${ }^{104}$

The power of the instrument is so great that Attila can be seen patting the heads of the horses. As Renea passes the occhiale to her compatriots, the poem's hero Aetio can recognize a Latin traitor taking shelter with the Huns; other Roman defenders can see the details on the Hun tents; and one Duke can recognize the warriors returning from a scouting expedition on their foreign horses. The telescope becomes an excuse to reveal the army of the enemy and rectifies the problem of distance and dust that had so bothered Galileo. As a result of the telescope's revelatory forces, the hero of the city, Aniceto, leads the band of survivors in a daring escape while the Hun camp sleeps, joining forces with the Roman army and Aetio's forces.

In a single canto, Strozzi has demonstrated more than a passing knowledge of Galileo and his philosophy. He borrows phrases and information from the Starry Messenger, the Letters on Sunspots, the Discourse on Floating Bodies, the Letter to Benedetto Castelli, the Letter to the Grand Duchess, and Galileo's private Considerazioni al Tasso. He alludes to Galileo in the Edificata, but Galileo's role is more than that of passing celebrity. Galileo's discoveries are not presented as simple lessons: they are masterfully blended into the structure and style of the poem and become necessary elements of the work.

\section{AFTER THE EDIFICATA}

After the publication of Venetia edificata in 1624, Strozzi continued pursuing his dual commitment to artistically uniting science and poetry and courting the Medici in Barbarigo, overo l'amico sollevato (Barbarigo, or the Relieved Friend, 1626), an epic poem dedicated to Cosimo II's brother, Prince Carlo de' Medici (1595-1666). ${ }^{105}$ The preface joins the contemporary

${ }^{104}$ Strozzi, 1624, 7.76.1-8: “Ed ecco il terzo giorno a' bei cristalli / Fissa l'occhio Renea, di veder vaga / Gli scelti fanti, e gli Hungheri cavalla, / Di cui non poco il lor gran Rè s'appaga. / E dopo lunghi, e nobili'ntervalli / Veniva armato il Rè di scetro, e daga, / Intorno a cui mille Guerrieri ardenti / Non sono in seguir lui mai satij, o lenti."

${ }^{105}$ Arnaudo provides a reading of the Barbargo that focuses on its civic function, with no mention of the Galilean connections. 
debate over which instruments are most reliable for scientific discovery, and contextualizes this within a traditionally conceived cosmos of well-defined and preestablished heavens. Strozzi's opening message to the reader uses the fictional device of the discovery of a star named for Venetian Niccolò Barbarigo (1579-1644) as a means to introduce the scientific debate. The naming of the star is meant to honor Barbarigo's heroic efforts as a friend to Marco Trevisan (1588-1674), but the device also permits Strozzi to speak about parallax: "I promised to find a way to tell you by means of parallax, in which heaven I found this new star. You yourself, from the appearance of other friendships, will be able to see that it is in the highest Heaven of Virtue." 106 Strozzi had promised his reader that he would explain how he used the apparent position of Barbarigo's star against the starry background to locate it in the night sky.

Arguments about parallax were based on the theory that the apparent location of an object changes when the observer moves, a method much disputed in the astronomical circles associated with the validation (or discrediting) of Galileo's discoveries. In the Dialogue of Cecco di Ronchitti (1605), a jocose dialogue in Paduan dialect frequently attributed to Galileo, a shepherd and his brother discuss and ridicule the university doctors of philosophy on a number of subjects, including "this awful mess about parallax." 107 By climbing trees and skinning knees, the two speakers demonstrate how the apparent position of a celestial body against a starry background would change if the earth moves, and the stars are fixed. Thus, a displacement caused by parallax would prove the Copernican theory. ${ }^{108}$ Parallax was contested to such a degree in early seventeenth-century intellectual circles because proliferation of astronomical observations made it possible to compare measurements of stellar motion made by telescopes located throughout Europe, and subsequently to draw conclusions about their location, size, shape, and speed based on the results recorded at different sites. ${ }^{109}$ The relatively limited sensitivity of telescopes at the time meant that observers could not register a change in perception of relative positions of sunspots, comets, or stars against a starry background. (In other words, the distance from the earth to the sun is so immense that a small magnification by refracting lenses would make no perceptible difference in

${ }^{106}$ Strozzi, 1626a, iii: "Io ti promisi col mezzo della parallasse di saperti dire, in che Cielo io trovava questa nuova stella. Tu stesso dalla comparazione dell'altre amicizie potrai vedere, ch'ella è nel più alto Cielo della Virtù."

${ }^{107}$ Drake, 1976, 43

${ }^{108}$ Ibid., 43-49.

${ }^{109}$ Hirshfeld, 112-33. 
how the observer sees the location of the celestial body or any marks upon its surface relative to the other stars.) Galileo initiated the discussion when he published the Letters on the Sunspots, a foundational text for passages in both the Venetia edificata and Barbarigo. Strozzi claims to use the comparatione, the appearance, in the sense of being seen for the first time, of other friendships to triangulate and define the origins of Barbarigo's actions on his friend's behalf. Lodged in traditional astrology and still at the intellectual forefront of the day, Strozzi's remark speaks to his own intellectual preoccupations as well as those of his presumed audience.

Though Galileo is absent from Strozzi's later Venetian theatrical works, a piece of propaganda that resulted from the success of Strozzi's Finta pazza, called Il Cannocchiale per la Finta pazza, shows that Strozzi's public was still making literary-scientific connections. A friend of the play's financial backer wrote the Cannocchiale shortly after seeing the Finta pazza performed at the Teatro Novissimo in January 1641. The title would initially suggest a renewed polemic over poetics, akin to the one over Giambattista Marino's (1569-1625) Adone (1623), criticized by Tomaso Stigliani (1573-1651) in his Dello occhiale opera defensiva (The Spyglass, a Defensive Work, 1627). Marino's supporters responded with a volley of works: Scipione Herrico's (1592-1670) Occhiale Appannato (Tarnished Spyglass, 1629), Agostino Lampugnani's (ca. 1586-ca. 1640) Antiocchiale (Anti-spyglass, 1629), and Angelico Aprosio's (1607-81) Occhiale stritolato (Smashed Spyglass, 1642). ${ }^{110}$ Here, instead, the optics of the Cannocchiale aim to reduce the physical distance that separates viewers from the spectacle.

Strozzi's Finta pazza was first staged to great acclaim at the Teatro Novissimo, an institution inspired by members of the Accademia degli Incogniti after Cesare Cremonini's tenure there. Ellen Rosand identified this work as "the first and possibly the greatest operatic 'hit' of the century."111 This now relatively unknown piece demonstrates that in the world of fiction the repercussions of Galileo's work continued past the period of new discoveries. The scope of the Cannocchiale was to describe the magnificent stage settings and the stage techniques used during the piece. The financial backer was clear about the connection he hoped readers would make between the title of the work and its content: "Throughout the centuries the discovery will be admired that, by means of two glasses, one convex and one concave, and by two contrary forces, the tiniest details never observed before are seen from the earth to the sky, not just of shadows, or recesses, or stars in the moon, but the little lights that serve as satellites around Jupiter and

\footnotetext{
${ }^{110}$ Battistini, 36.

${ }^{111}$ E. Rosand, 2007, 88.
} 
others in the Milky Way. I have been considering these days the composition the Finta pazza by Giulio Strozzi, with stage machines by Iacopo Torelli, and music devised by Francesco Sacrati, and they are a sky worthy of being contemplated by everyone, but being so far away from a majority of people, they would be deprived of a great value, having already come to see such a noble creation, if it were not made easy to everyone to see and admire it." ${ }^{\prime 12}$ The author aimed to create a telescope from prose, one that would make even the smallest of theatrical details available to curious spectators who were unable to attend the performances of the Finta pazza. In so doing, he made explicit the latent connections between Strozzi's artistic project and Galileo's methods of discovery in natural philosophy. The financial backer noted that the man he had commissioned to write the description of the stage apparatus chose the title: "he wanted to call it the Cannocchiale not only because it is useful at every distance, but because of the few observations he was allowed to make in the quick time given him about morality and art." author of the Cannocchiale, Strozzi's play disseminated the observations of Galileo's Starry Messenger to a wide audience, just as the telescope's physical function of magnification made distant realities more immediately visible. This explicit pairing of Strozzi's theater with Galileo's astronomy shows that audiences were still very familiar with Strozzi's long engagement with Galileo's ideas, even if he had long since stopped including those allusions in his works.

Strozzi's commitment to natural philosophy in his works of poetry is notable. Rather than simply honoring Galileo in a single line or predicting that a telescope would be invented, he tried to blend poetry and philosophy, borrowing terminology from the latter to explain his strategies in the former. In addition to this influence on the content of Strozzi's work, Galileo provided the model and also served as the medium for his aims to gain Medici patronage in Florence. Beyond these textual connections that link

${ }^{112}$ M. B. C. di G., 283: "Sarà nei secoli ammirabile quel trovato che per mezzo di due vetri, l'un convesso e l'altro concavo, per forza di due contrari si vedono dalla terra in cielo minutezze non prima osservate, non solo di ombre o di concavi o di stelle nella Luna, ma di minute facelle che servono di satellizio a Giove et altre nella Via Lattea. Io considerava questi giorni che la composizione del sig. Giulio Strozzi della Finta Pazza, le macchine ritrovate dal sig. Iacomo Torelli e la musica orditavi sopra dal sig. Francesco Sacrati eran un cielo degno d'esser contemplato da tutti, ma così lontano a gran parte dalle genti, che era un togliere il pregio a tanti, che sono concorsi a sì nobile fattura, se non si faceva comodo ad ognuno di vederla et ammirare."

${ }^{113}$ Ibid.: "ei l'ha voluta dire il Cannocchiale perché serve non solo ad ogni distanza, ma per quelle poche osservazioni, che la velocità del tempo gli ha permesso di toccare, o di morale o d'arte." 
the two authors, for Strozzi's audiences his theatrical pieces evoke the use of Galileo's greatest instrument, and Strozzi himself associates with a learned crowd that also has an interest in the astronomical debates of the period. Seen in the context of his entire body of work, Strozzi's praise of the Venetian republic in the Venetia edificata, while in line with other epics of the period, represents the elaborate example of a lifetime of artistic work dedicated to the exploration of what Galileo's philosophy could offer to the narratives, themes, poetics, and patrons of seventeenth-century fiction.

UNIVERSITY OF KANSAS 


\section{Bibliography}

Ait-Touati, Federique. Fictions of the Cosmos. Trans. Susan Emanuel. Chicago, 2011. Arnaudo, Marco. "Il Barbarigo di Giulio Strozzi. Un esperimento di epica civica nella Venezia del Seicento." Studi secenteschi 51 (2010): 3-33.

Bartolomei, Girolamo. L'America. Poema eroico di Girolamo Bartolomei Già Smeducci. Rome, 1650.

Battistini, Andrea. Galileo e i gesuiti: miti letterari e retorica della scienza. Milan, 2000.

Biagioli, Mario. Galileo Courtier: The Practice of Science in the Culture of Absolutism. Chicago, 1993.

- Galileo's Instruments of Credit. Chicago, 2006.

"Did Galileo Copy the Telescope? A 'New' Letter by Paolo Sarpi." In The Origins of the Telescope, ed. Albert van Helden, Sven Dupré, Rob van Ghent, and Huib Zuidervaar, 203-30. Helsinki, 2010.

Bouwsma, William J. Venice and the Defense of Republican Liberty. Berkeley, 1968.

Bucciantini, Massimo. Galileo e Keplero. Filosofia, cosmologia e teologia nell'Età della Controriforma. Turin, 2003.

Camporesi, Piero. I balsami di Venere. Milan, 1989.

Cole, Janie. "Cultural Clientelism and Brokerage Networks in Early Modern Florence and Rome: New Correspondence between the Barberini and Michelangelo Buonarroti the Younger." Renaissance Quarterly 60.3 (2007): 729-88.

Consalvi, Antonio. Il consiglio delli Dei per la fondatione, e grandezza dell'Inclita Città di Venetia, et dell'Eccellentissima sua Republica. Favola maritima di Antonio Maria Consalvi. Al Ser.mo Prencipe Marc'Antonio Memmo. Vicenza, 1614.
Cremonini, Cesare. Il Nascimento di Venetia. Bergamo, 1617.

Dick, Hugh G. "The Telescope and the Comic Imagination." Modern Language Notes 58.7 (1943): 544-48.

Doglioni, Nicolò. Compendio Historico Universale di tutte le cose notabili successe nel Mondo, dal principio della sua creatione sin'hora: Dedicato già all'Illustriss. Sig. Leonardo Donato, Cavalier, \& meretissimo Procurator di S. Marco, \& poi Sereniss. Prencipe di Venetia. Ma di nuovo hora dall'Auttore la quarta volta riveduto, corretto, \& ampliato con nuova aggiunta sino all'anno 1618. Venice, 1622.

Drake, Stillman. Galileo Against the Philosophers in His Dialogue of Cecco di Ronchitti (1605) and Considerations of Alimberto Mauri (1606). Los Angeles, 1976.

- Galileo at Work: His Scientific Biography. Chicago, 1978.

Ferrari, Luigi. Onomasticon. Repertorio biobibliografico degli scrittori italiani dal 1501 al 1830. Milan, 1947.

Galilei, Galileo. Le opere di Galileo Galilei. Ed. Antonio Favaro and Isidoro del Lungo. 20 vols. 1890-1909. Reprint, Florence, 1964-66.

- Sidereus nuncius or The Sidereal Messenger. Ed. and trans. Albert Van Helden. Chicago, 1989.

- Sidereus nuncius. Ed. Andrea Battistini. Trans. Maria Timpanaro Cardini. Venice, 1993.

-. On Sunspots: Galileo Galilei and Christoph Scheiner. Ed. and trans. Eileen Reeves and Albert Van Helden. Chicago, 2010.

Grendler, Paul F. The Roman Inquisition and the Venetian Press, 1540-1605. Princeton, 1977.

Heilbron, John. Galileo. Oxford, 2010. 
Hill, John Walter. "Oratory Music in Florence, I: Recitar cantando, 1583-1655." Acta musicologica 51.1 (1979): 108-36.

Hirshfeld, Adam. Parallax: The Race to Measure the Cosmos. New York, 2001.

Livello, Ottavio. Concettione di Venetia. Venice, 1624.

Macandrew, Hugh. "Vouet's Portrait of Giulio Strozzi and its Pendant by Tinelli of Nicolò Crasso." The Burlington Magazine 109.770 (1967): 266-74.

Marinelli, Lucrezia. L'Enrico overo Bisantio acquistato, poema heroico. Venice, 1635.

M. B. C. di G. Il Cannocchiale per la Finta Pazza. Drama dello Strozzi. 1641. Reproduced in Alessandra Chiarelli and Angelo Pompilio, "Or vaghi or fieri" Cenni di poetica nei libretti veneziani (circa 1640-1740). Con l'edizione de Il cannocchiale per la "Finta Pazza" di Maiolino Bisaccioni, ed. Cesarino Ruini, 281-94. Bologna, 2004.

Michaud, Joseph, Fr., and Louis Gabriel, eds. Biographie universelle, ancienne et moderne. 85 vols. Paris, 1811-62.

Michelassi, Nicolà. "La Finta pazza a Firenze: Commedie 'spagnole' e 'veneziane' nel teatro di Baldracca (1641-1665)." Studi secenteschi 41 (2000): 313-53.

Milton, John. Paradise Lost. Ed. Stephen Orgel and Jonathan Goldberg. Oxford, 2004.

Morosini, Andrea. Historia Veneta ab anno MDXXI usque ad annum MDCXV. Venice, 1623.

Morosini, Paolo. Historia della città, $e$ republica di Venetia. Venice, 1637.

Muir, Edward. Civic Ritual in Renaissance Venice. Princeton, 1981.

- The Culture Wars of the Late Renaissance. Cambridge, MA, 2007.

Negri, Giulio. Istoria degli scrittori fiorentini. Ferrara, 1722.

Onofri, Fedele. Cronologia veneta. Nella quale fedelmente, e con brevità si descrivono le cose più notabili di questa famosissima Città di Venetia sino all'anno 1663. Venice, 1643.

Osthoff, Wolfgang. "Maschera e musica." Nuova rivista musicale italiana 1 (1967): 16-44.

Pallavicino, Ferrante. Panegirici, epitalami, discorsi accademici, novelle, et lettere amorose. Venice, 1649.

Pancetti da Serravalle, Camillo. Venetia libera, poema heroico del Sig. Camillo Pancetti da Serravalle. Venice, 1622.

Picciotto, Joanna. Labors of Innocence in Early Modern England. Cambridge, MA, 2010.

Pirrotta, N. Enciclopedia dello Spettacolo. 9 vols. Rome, 1954-62.

Porta, Giambattista della. Natural Magick. Ed. Derek J. Price. New York, 1957.

Reeves, Eileen. Galileo's Glassworks: The Telescope and the Mirror. Cambridge, MA, 2008.

Rosand, David. Myths of Venice: The Figuration of a State. Chapel Hill, 2001.

Rosand, Ellen. Opera in Seventeenth-Century Venice: The Creation of a Genre. Berkeley, 1990.

- Monteverdi's Last Operas: A Venetian Trilogy. Berkeley, 2007.

Sansovino, Francesco. Venetia città nobilissima et singolare, descritta in XIIII. libri da M. Francesco Sansovino. Venice, 1663.

Soranzo, G. Bibliografia veneziana in aggiunta e continuazione del "Saggio" di E. A. Cicogna. Venice, 1885.

Spiller, Elizabeth A. "Reading Through Galileo's Telescope: Margaret Cavendish and the Experience of Reading." Renaissance Quarterly 53.1 (2000): 192-221.

Steiner, Calro. Cristoforo Colombo nella poesia epica italiana. Voghera, 1891.

Strozzi, Giulio. Orazione funebre recitata nell'Esequie fatte in Roma dalla Nazione Fiorentina al Ser. Ferdinando I Il Gran Duca di Toscana. Venice, 1609. 
Erotilla di Giulio Strozzi per le nozze de gli Eccell.mi Principi D. Marcantonio Borghese et D. Camilla Orsina. Venice, 1615.

-. Esequie fatte in Venetia dalla natione Fiorentina al Serenissimo D. Cosimo II Quarto Gran Duca di Toscana. Il dì 25 di Maggio, 1621. Venice, 1621a.

I primi dodici canti della Venetia edificata poema eroico. E de'saggi Poetici di Giulio Strozzi. Venice, 1621b.

La Venetia edificata. Poema heroico di Giulio Strozzi. Venice, 1624.

Il Barbarigo, over l'Amico sollevato. Poema eroico di Giulio Strozzi. Con Licenza, e Privilegio. Venice, 1626 .

- La Venetia edificata. Venice, $1626 b$.

- Le sette giornate nelle quali hebbe

Venetia $i$ serenissimi principi $d$.

Ferdinando II Gran Duca di Toscana e d. Gio. Carlo de' Medici suo fratello sonetti. Venice, 1628.

- La Delia o sia la Sera sposa del Sole.

Poema drammatico di Giulio Strozzi. Venice, 1639.
. La Finta savia. Drama di Giulio Strozzi. Venice, 1643.

- La vita di Lazzariglio del Torme. Traduzione secentesca di Giulio Strozzi. Ed. Aldo Ruffinato. Naples, 1990.

Tasso, Torquato. Jerusalem Delivered. Ed. and trans. Anthony M. Esolen. Baltimore, 2000.

Unglaub, Jonathan. Poussin and the Poetics of Painting: Pictorial Narrative and the Legacy of Tasso. Cambridge, 2006.

Vaccaluzzo, Nunzio. Galileo nella poesia del suo secolo. Milan, 1910.

Van Helden, Albert. The Invention of the Telescope. 2nd ed., Philadelphia, 2008.

Vivo, Filippo de. Information and Communication in Venice: Rethinking Early Modern Politics. Oxford, 2007.

Westfall, Richard. "Scientific Patronage: Galileo and the Telescope." Isis 76 (1985): 18-22.

Whitaker, Ewen. "Galileo's Lunar Observations." Journal for the History of Astronomy 9 (1978): 155-69.

Wlassics, Tibor. Galileo critico letterario. Ravenna, 1974. 
Copyright of Renaissance Quarterly is the property of University of Chicago Press and its content may not be copied or emailed to multiple sites or posted to a listserv without the copyright holder's express written permission. However, users may print, download, or email articles for individual use. 